\title{
PENGEMBANGAN BAHAN AJAR E-BOOK BERBASIS MODEL PROBLEM BASED INSTRUCTION MATA KULIAH MANAJEMEN PERTUJUKAN PADA MAHASISWA SASTRA INDONESIA UNIMED
}

\author{
Hera Chairunisa, Ita Khairani, Muharrina Harahap \\ Surel: herawenas@unimed.ac.id
}

\begin{abstract}
This study aims to develop product development of E-Book Teaching Materials Based on Problem Based Instruction Models for Performance Management Courses for Indonesian Literature Students Unimed. The research method uses research and development $(R \& D)$ methods from the ADDIE $R \& D$ model (Analysis, Design, Development, Implementation, and Evaluation). The research sample was the entire population of 25 Indonesian language and literature study program students in the fifth semester (V) of the 2020/2021 academic year. The results of research conducted in the development of product developmentof $E$ Book Teaching Materials Based on the Problem Based Instruction Management Course Model. Based on the average Pre-Test results, it can be seen that $1=63.5$ and the average Post-Test results can be seen that $2=80$, indicating that the Post-Test results have increased by 16.5, so there is a significant difference in the mean. There is a significant difference between student learning outcomes before and after using E-Book Teaching Materials Based on Problem Based Instruction Models for Performance Management Courses. Thus, it can be concluded that the product of E-Book Teaching Materials Based on the Problem Based Instruction Model for the Performance Management Course is feasible, practical, and effective to be usedfor Unimed Indonesian Literature Students.
\end{abstract}

Keywords: Teaching Materials, E-Book, Model, Problem Based Instruction, Management, Performance

\begin{abstract}
ABSTRAK
Penelitian ini bertujuan untuk membuat Pengembangan produk Bahan Ajar EBook Berbasis Model Problem Based Instruction Mata Kuliah Manajemen Pertunjukan untuk Mahasiswa Sastra Indonesia Unimed. Metode penelitian menggunakan metode research and development $(R \& D)$ dari model $R \& D$ ADDIE (Analysis, Design, Development, Implementation, and Evaluation). Sampel penelitian adalah seluruh populasi mahasiswa program studi bahasa dan sastra Indonesia semester Lima (V) tahun ajaran 2020/2021 berjumlah 25 orang. Hasil penelitian yang dilakukan dalam pengembangan Pengembangan produk Bahan Ajar E-Book Berbasis Model Problem Based Instruction Mata Kuliah Manajemen. Berdasarkan rata-rata hasil Pre-Test dapat diketahui bahwa $x_{1}=63,5$ dan rata-rata hasil Post-Test dapat diketahui bahwa $x_{2}=80$, menunjukkan bahwa hasil Post-Test mengalami peningkatan 16,5, sehingga terdapat perbedaan ratarata yang signifikan antara hasil belajar mahasiswa sebelum dan sesudah menggunakan Bahan Ajar E-Book Berbasis Model Problem Based Instruction Mata Kuliah Manajemen Pertunjukan. Dengan demikian dapat disimpulkan bahwa produk Bahan Ajar E-Book Berbasis Model Problem Based Instruction Mata Kuliah Manajemen Pertunjukan layak, praktis, dan efektif digunakan untuk Mahasiswa Sastra Indonesia Unimed.
\end{abstract}

Kata Kunci: Bahan Ajar, E-Book, Model, Problem Based Instruction, Manajemen, Pertunjukan 


\section{PENDAHULUAN}

Manajemen

Pertujukan

merupakan mata kuliah yang bertujuan untuk memberikan kompetensi untuk memiliki penguasaan pengetahuan, pemahaman dan pengalaman yang meliputi: Organisasi Seni dalam Pertunjukan, pada konsep dasar manajemen, dan juga proses perencanaan sebuah pertunjukan, serta penyelenggaraan sebuah pertunjukan. Metode pembelajaran umumnya menggunakan metode ceramah, dan diskusi, serta penugasan, akan tetapi, masih banyak ditemukan mahasiswa yang pasif. Hal ini terlihat dari nilai formatif yang hanya memperoleh $70 \%$ artinya ada $30 \%$ mahasiswa yang kurang kompeten. Penyebaran pandemi COVID-19 mengharuskan perguruan tinggi untuk melakukan perkuliahan secara daring. Sehingga peneliti menghadapi fenomena baru mengenai sistem berkuliahan.

Permasalahan di atas jika dihubungkan dengan hasil perkuliahan di tatap muka untuk angkatan 2017 yang sudah menggambil mata kuliah Manajemen Pertujukan dengan tatap muka dikampus nilai yang diperoleh $30 \%$ mahasiswa yang kurang kompeten. Jika Pandemi Virus Corona berlajut disemester ganjil tahun pembelajaran 2020/2021 untuk mahasiswa angkatan 2018 yang akan mengambil mata kuliah Manajemen Pertunjukan meningkatkan kecemasan dosen pengampu sebagai peneliti mengenai kompetensi yang akan diperoleh di akhir perkuliahan.

Berdasarkan pengumuman yang dilakukan Menteri Pendidikan dan
Kebudayaan Nadiem Makarim (2020) mengaku tengah mengkaji kemungkinan penerapan kurikulum darurat akibat kondisi yang mengharuskan belajar di rumah selama pandemi virus corona (Covid19). Selain itu, para murid atau mahasiswa juga mesti siap beradaptasi dengan perubahan pembelajaran yang diatur oleh sekolah dan universitas. Remote learning dapat dipandang lebih bebas dan fleksibel diakses dari rumah.

Berdasarkan surat edaran Rektor Unimed dan pernyataan Menteri Pendidikan dan Kebudayaan serta permasalahan pandemi Virus Corona yang tidak pasti kapan berakhir, maka peneliti mengantisipasi fenomena yang terjadi dalam pembelajaran Manajemen Pertunjukan kurang optimal. Dengan mendiagnosis hasil belajar antara lain: (1) Sulitnya mahasiswa memahami manajemen pertunjukkan, (2) Sulitnya mahasiswa menjelaskan ruang lingkup matakuliah, (3) mampu memahami profil organisasi pertunjukan, (4) Sulitnya mahasiswa merencanakan pertunjukan karya sastra, dan (5) Sulitnya mahasiswa menyelenggarakan sebuah pertunujukan. Metode pembelajaran Manajemen Pertunjukan yang digunakan sebelumnya adalah on line person atau dibimbing secara langsung, Pembimbingan secara langsung tersebut menyebabkan proses belajar mengajar yang dijalankan menjadi teacher centered learning (TCL).

Berdasarkan masalah di atas maka peneliti merencakan Optimalisasi 
Perencanaan Pembelajaran mata

kuliah Seni Pertunjukan

direncanakan dengan sistem

perkulihan daring digunakan secara

tepat dan jelas. Maka dibuatlah

gagasan pemecahan isu yakni

'Pengembangan Bahan Ajar E-Book

Berbasis Model Problem Based

Instruction Mata Kuliah Manajemen

Pertunjukan untuk Mahasiswa Sastra

Indonesia Unimed'. Dengan alasan tersebut juga peneliti berinisiatif membuat e-Book yang kreatif, interaktif, manarik dan informatif.

Dengan demikian diharapkan penyampaian materi elektronika digital lebih maksimal, semakin mudah dipahami oleh peserta didik, peserta didik tidak merasa bosan dalam menerima pelajaran, serta dapat termotivasi untuk mempelajari lebih lanjut. Selain itu, dengan e-Book diharapkan peserta didik tidak hanya termotivasi pada saat pelajaran berlangsung tetapi juga termotivasi untuk belajar di luar jam pelajaran dan mampu bereksperimen terkait dengan materi yang disampaikan. Selain itu juga mahasiswa diberikan materi tambahan guna memahami lebih luas materi yang mungkin belum bisa tersampaikan langsung ketika melaksanakan perkuliahan daring. Melalui perencanaan pengembangan Digital Book ini diharapkan nantinya bisa mengatasi permasalahan yang ada seperti perencanaan perkuliahan diperkaya dan menarik bagi mahasiswa sehingga dapat diakses kapan pun dan dimana saja.

\section{METODOLOGI PENELITIAN}

Peneliti menggunakan metode research and development $(\mathrm{R} \& \mathrm{D})$ dari model R\&D ADDIE (Analysis, Design, Development, Implementation, and Evaluation). Menurut Romiszowski ADDIE model desain pembelajaran sistematik sebagai aspek prosedural pendekatan sistem telah diwujudkan dalam banyak praktik metodologi untuk desain dan pengembangan teks, materi, audiovisual dan materi pembelajaran berbasis komputer. Dengan model penelitian ini produk yang dihasilkan berupa digital book dengan tujuan agar mempermudah kegiatan belajar antara dosen dan mahasiswa yang berimplementasikan terhadap pencapaian tujuan pendidikan. Adapun tahapan penelitian dan pengembangan ini meliputi:

1. Analysis (Analisis)

2. Design ( Perancangan)

3. Development ( Pengembangan)

4. Implementation (Implementasi)

5. Evaluation (Evaluasi) (Sugiyono, 2015: 200)

Bagan prosedural pada penelitian ini adalah berikut ini: 


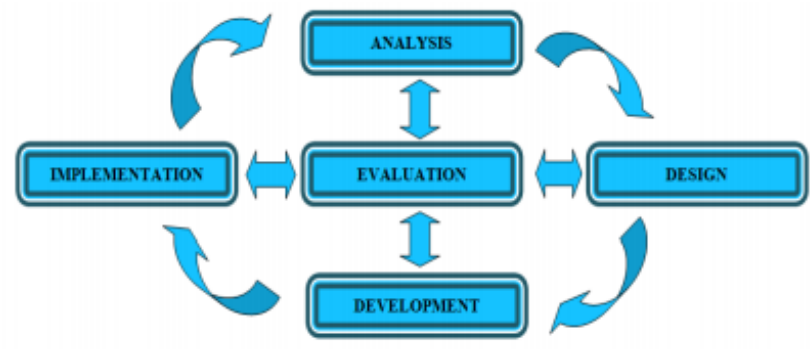

\section{Gambar 1. Metode Research and Development (R\&D) Model ADDIE (Sugiyono, 2015: 200)}

Kegiatan ini akan dilakukan pada waktu dan tempat sesuai dengan perkuliahan mata kuliah Manajemen Pertunjukan di jurusan Bahasa dan Sastra Indonesia. Populasi seluruh mahasiswa Sastra Indonesia stambuk 2019 berjumlah 25 orang. Sampel penelitian adalah seluruh populasi mahasiswa program studi Bahasa dan Sastra Indonesia semester Lima (V) tahun ajaran 2020/2021 berjumlah 25 orang.

\section{HASIL PENELITIAN DAN PEMBAHASAN}

Hasil penelitian uji kelayakan ahli materi sebanyak dua kali. Berdasarkan perolehan hasil validasi pertama, materi Bahan Ajar E-Book Berbasis Model Problem Based Instruction Mata Kuliah Manajemen Pertunjukan diperoleh nilai kelayakan mencapai $46 \%$ jika disesuaikan pada tabel kelayakan jadi skor tersebut termasuk pada kualifikasi tidak layak dan keputusan yang diambil yaitu revisi total. Berdasarkan perolehan hasil validasi kedua ahli materi terhadap Bahan Ajar E-Book Berbasis Model Problem Based Instruction Mata Kuliah Manajemen Pertunjukan diperoleh kelayakan mencapai 92\%, disesuaikan pada tabel kelayakan termasuk pada kualifikasi sangat layak.

Penilaian ahli media diperoleh dari angket yang diberikan kepada validator/ahli media, diperolehan hasil validasi ahli media Bahan Ajar E-Book Berbasis Model Problem Based Instruction Mata Kuliah Manajemen Pertunjukan dengan nilai kelayakan mencapai 90,6 \%, jika disesuaikan pada tabel kelayakan jadi skor tersebut termasuk pada kualifikasi sangat layak dan keputusan yang diambil yaitu tidak perlu revisi. Validasi Ahli Praktisi diperoleh Penilaian nilai kelayakan mencapai 93,3\% jika disesuaikan pada tabel kelayakan jadi skor tersebut termasuk pada kualifikasi sangat layak dan keputusan yang diambil yaitu tidak perlu revisi.

Efektivitas Bahan Ajar E-Book Berbasis Model Problem Based Instruction Mata Kuliah Manajemen Pertunjukan. Pencapaian dapat melalui tes awal dan tes lanjutan yang dilakukan pada mahasiswa Semester V Jurusan Bahasa dan Sastra Indonesia. Data dari nilai Pre-Test Digunakan untuk mengetahui kemampuan dan tingkat pengetahuan mahasiswa sebelum menerima 
perlakuan. Selain itu, mahasiswa mendapatkan perlakuan dengan Bahan Ajar E-Book Berbasis Model Problem Based Instruction yang dikembangkan, data hasil dari perlakuan tersebut diperoleh dari nilai hasil Post-Test.

Hasil rata-rata nilai mahasiswa yang diperoleh dari 20 orang mahasiswa yaitu 63,5, artinya hasil belajar atau kentutasan belajar mahasiswa masih kurang baik. Dengan jumlah siswa yang tuntas hanya mencapai 9 orang (45\%), sedangkan mahasiswa yang tidak tuntas berjumlah 11 orang (55\%). Hasil tersebut masih jauh dari kriteria ketuntasan klasikal yaitu $85 \%$. Berdasarkan hasil diatas, maka peneliti melakukan proses pembelajaran yaitu dengan memberikan menggunakan Bahan Ajar E-Book Berbasis Model Problem Based Instruction untuk mengetahui tingkat keberhasilan proses pembelajaran. Hasil Post-Test diperoleh dari jumlah 20 orang, terdapat 17 orang $(85 \%)$ mahasiswa yang tuntas, dan mahasiswa yang tidak tuntas sebanyak 3 orang (15\%). Disimpulkan bahwa persentase mahasiswa yang tuntas lebih tinggi daripada mahasiswa yang tidak tuntas. Dengan demikian ketuntasan belajar mahasiswa telah mencapai ketuntasan klasikal yaitu $85 \%$. Dari hasil nilai Pre-Test dan Post-Test maka dilakukan analisis lainnya melalui $t$ test dependent (Paired Sample t-test) atau uji-t. Teknik analisis ini digunakan untuk mengetahui apakah ada pengaruh perlakuan yang diberikan kepada subjek penelitian melalui pengembangan produk Bahan Ajar E-Book Berbasis Model Problem Based Instruction. Adapun langkahlangkah analisis data sebagai berikut:

- Menentukan Hipotesis

$H_{0}=$ Tidak ada perbedaan yang signifikan antara hasil belajar siswa sebelum dan sesudah menggunakan produk/media yang dikembangkan

$H_{1}=$ Ada perbedaan yang signifikan antara hasil belajar siswa sebelum dan sesudah menggunakan produk/media yang dikembangkan

- Menetapkan Level of Significant (a') dan Degree of Freedom (df)

a. Tingkat signifikan $\left(a^{\prime}\right)=0,05$

b. Derajat kebebasan $=\mathrm{n}-1$

- Menentukan Kriteria Pengujian

Jika thitung $>t_{\text {tabel }}$ atau probalitas kesalahan < 0,05, maka $H_{1}$ diterima dan $H_{0}$ ditolak. Jika $t_{\text {hitung }}<t_{\text {tabel }}$ atau probalitas kesalahan > 0,05, artinya $H_{1}$ ditolak dan $H_{0}$ diterima.

- Menentukan hasil statistik pada pre-test dan post-test dengan rumus paired samplet-test

Berdasarkan nilai yang didapat dari perhitungan $t_{\text {hitung }}=4,37>t_{\text {tabel }}=$ 2,631 sehingga terdapat perbedaan rata-rata yang signifikan antara hasil belajar mahasiswa sebelum dan sesudah menggunakan Bahan Ajar EBook Berbasis Model Problem Based Instruction, maka $H_{1}$ diterima $H_{0}$ ditolak. Berdasarkan hasil rata-rata 
hasil Pre-Test bahwa $x_{1}=63,5$ dan rata-rata hasil Post-Test bahwa $x_{2}=$ 80, menunjukkan bahwa hasil PostTest mengalami peningkatan 16,5 .

\section{Pembahasan}

Produk yang dikembangkan dalam penelitian ini adalah Pengembangan produk Bahan Ajar EBook Berbasis Model Problem Based Instruction Mata Kuliah Manajemen Pertunjukan. Media menggunakan model ADDIE yaitu analisis, desain, pengembangan, penerapan, dan evaluasi. Tahap pertama yaitu analisis, tahap analisis yang dilakukan yaitu analisis kompetensi, analisis karakteristik, dan analisis materi. Tahap kedua yaitu desain, pada tahap ini peneliti membuat rancangan dari hal yang telah dianalisa berdasarkan kebutuhan mahasiswa Bahasa dan Sastra Indonesia. Langkah-langkah pada tahap ini mengacu pada Pengembangan produk Bahan Ajar EBook Berbasis Model Problem Based Instruction Mata Kuliah Manajemen Pertunjukan dan menguraikan kisi-kisi wawancara dan observasi sebagai analisis kebutuhan dosen dan mahasiswa, perencanaan desain Bahan Ajar E-Book Berbasis Model Problem Based Instruction, serta perencanaan kelengkapan Bahan Ajar E-Book Berbasis Model Problem Based Instruction. Tahap ketiga yaitu Pengembangan, produk mulai ikembangkan sesuai dengan desain yang disiapkan. Bahan Ajar E-Book Berbasis Model Problem Based Instruction dimulai dari pengumpulan bahan yang telah dibuat terlebih dahulu. Setelah itu, media yang dibuat akan divalidasi oleh ahli materi dan media (validator). Setelah media layak, maka peneliti akan melakukan uji coba media kepada siswa. Tahap keempat yaitu Penerapan. Tahap penerapan adalah langkah-langkah khusus untuk menerapkan sistem pembelajaran, segala sesuatu yang disampaikan sesuai dengan materi pembelajaran. Pada tahap ini, media yang dikembangkan akan di uji coba. Pengembangan media direalisasikan dalam bentuk uji lapangan yang memiliki fungsi untuk mengetahui kelayakan, praktikalitas, dan keefektifan penggunaan media dalam proses pembelajaran. Pada tahap ini peneliti memperoleh hasil uji coba kelayakan Bahan Ajar E-Book Berbasis Model Problem Based Instruction sudah layak dan dapat digunakan sebagai salah satu bahan ajar dalam Mata Kuliah Manajemen Pertunjukan. dengan persentase kelayakan dari ahli materi sebanyak 92 $\%$, dari ahli media sebanyak 90,6\%, dari ahli pembelajaran sebanyak 93,3 $\%$.

Hasil uji coba keefektifan penggunaan Bahan Ajar E-Book Berbasis Model Problem Based Instruction meningkatkan hasil belajar mahasiswa yaitu hasil pretest sebanyak 9 mahasiswa atau sebanyak $45 \%$ mahasiswa yang tuntas, sedangkan 11 siswa atau sebesar 55\% siswa tidak tuntas, dengan nilai ratarata yang diperoleh sebesar 63,5. Hasil Post-Test ketuntasan siswa meningkat dari sebelumnya, yaitu 17 siswa mendapat nilai tuntas atau sebanyak 
85\% sedangkan 3 mahasiswa lainnya belum tuntas yaitu sebesar $15 \%$, dengan nilai rata-rata yang diperoleh sebesar 80. Persentase ketuntasan meningkat dari Pre-Test ke Post-Test. Dengan ini dapat dilihat adanya pengaruh dari penggunaan Bahan Ajar E-Book Berbasis Model Problem Based Instruction terhadap hasil belajar mahasiswa.

\section{SIMPULAN}

Berdasarkan hasil penelitian dan pembahasan dapat disimpulkan di bawah ini. Hasil uji kelayakan Pengembangan produk Bahan Ajar EBook Berbasis Model Problem Based Instruction Mata Kuliah Manajemen Pertunjukan untuk Mahasiswa Sastra Indonesia Unimed dapat direalisasikan dan sudah layak tanpa revisi dan dapat digunakan sebagai salah satu media pembelajaran dengan persentase kelayakan dari ahli materi sebanyak 92 $\%$, dari ahli media sebanyak 90,6 \%, dari ahli praktisi pembelajaran sebanyak 93,3\%.

Hasil pada test awal (Pre-Test) diperoleh 9 mahasiswa atau sebanyak $45 \%$ siswa yang tuntas, sedangkan 11 mahasiswa atau sebesar $55 \%$ siswa tidak tuntas, dengan nilai rata-rata yang diperoleh sebesar63,5. Hasil test selanjutnya (Post-Test) ketuntasan siswa meningkat dari sebelumnya, yaitu 17 mahasiswa mendapat nilai tuntas atau sebanyak $85 \%$ sedangkan 3 mahasiswa lainnya belum tuntas yaitu sebesar $15 \%$, dengan nilai rata-rata yang diperoleh sebesar 80. Persentase ketuntasan meningkat dari Pre-Test ke Post-Test.
Hasil uji coba keefektifan penggunaan Bahan Ajar E-Book Berbasis Model Problem Based Instruction Mata Kuliah Manajemen Pertunjukan dapat dilihat dari penggunaan dapat meningkatkan hasil belajar mahasiswa. Berdasarkan nilai Pre-Test dan Post-Test tersebut maka dilakukan analisis lebih lanjut melalui uji-t. Berdasarkan nilai yang didapat dari perhitungan $t_{\text {hitung }}=4,37$ $>t_{\text {tabel }}=2,631$, maka $H_{1}$ diterima $H_{0}$ ditolak. Berdasarkan rata- rata hasil Pre-Test dapat diketahui bahwa $x_{1}=$ 63,5 dan rata-rata hasil Post-Test dapat diketahui bahwa $x_{2}=80$, menunjukkan bahwa hasil Post-Test mengalami peningkatan 16,5, sehingga terdapat perbedaan rata-rata yang signifikan antara hasil belajar mahasiswa sebelum dan sesudah menggunakan Bahan Ajar E-Book Berbasis Model Problem Based Instruction Mata Kuliah Manajemen Pertunjukan. Produk pengembangan Bahan Ajar E-Book Berbasis Model Problem Based Instruction Mata Kuliah Manajemen Pertunjukan untuk Mahasiswa Sastra Indonesia Unimed layak, praktis, dan efektif digunakan dalam pembelajaran.

\section{DAFTAR RUJUKAN}

Gultom, Syamsul. 2020. Surat Edaran Rektor. Dikutip dari: https://www.unimed.ac.id/2020/03 /16/surat-edaran-rektor-tentangtindakan-pencegahan-penyebarancovid-19-di-unimed/). Medan, 16 Maret 2020 
Hera Chairunisa, Ita Khairani, Muharrina Harahap : Pengembangan Bahan Ajar ...

Ibrahim dan Muhammad Nur. 2005.

Pengajaran Berdasarkan Masalah.

Surabaya: University Press

Jazuli, M. 2001. Manajemen Produksi

Seni Pertunjukan. Yogyakarta:

Yayasan Lentera Budaya

Kasbolah, E.S. Kasihani. 1998.

Penelitian Tindakan Kelas (PTK).

Malang: Departemen Pendidikan

dan Kebudayaan

Kerlinger. 1998. Asas-Asas Penelitian

Behaviour, Edisi 3, Cetakan 7.

Yogyakarta: Gadjah Mada

University Press

Kemmis, S \& Mc Taggart, R. 1992.

The Action Research Planner.

Australia: Deakin University Press

Nadiem Makarim. 2020. Mendikbud

Nadiem Akui Tengah Kaji

Kurikulum Darurat Corona.

https://www.cnnindonesia.com/nas

ional/20200415171950-20-

493880/mendikbud-nadiem-akui-

tengah-kaji-kurikulum-darurat-

corona

Trianto. 2007. Model-Model

Pembelajaran Inovatif-Progresif.

Surabaya: Prenada Media Group. 